\title{
Internal audit perceptions and their impact on performance of the internal audit function.
}

\author{
${ }^{1}$ Sifile Obert, ${ }^{2}$ Innocent Ngwenya Munyunguma, \\ ${ }^{1}$ Chinhoyi University of Technology Lecturer, CUT, Bag 7724, Chinhoyi, Zimbabwe, \\ ${ }^{2}$ Internal auditor, Hwange Colliery Company, Zimbabwe,
}

\begin{abstract}
This research sought to examine the factors causing negative perceptions of internal audit and the impact on the performance of the internal audit function. The researcher used questionnaires to collect data. There were 78 questionnaires distributed and 69 were received giving a response rate of $88.46 \%$. The researcher used managers, section heads, supervisors and clerical staff as respondents. The research used exploratory and qualitative techniques. The causes of negative perceptions were agreed by $78 \%$ of respondents and some of the causes of negative perception were; auditors failure to meet expectation gap, bad reputation of an auditor, the quality of audit staff, level of professional competence and the absence of independence and objectivity in internal audits. The research proposed strategies which can be used to improve perceptions about internal audit as follows: Internal audit needs to adopt a new mindset in view of the many changes that are taking place in the business environment, to correct the anomalies when you receive a qualified audit opinion and correct the errors rather than change the auditor, in the prevalence of financial scandals, intense focus on corporate governance. Auditing can be improved by getting adequate support from management, recruiting qualified and professional auditors and management can improve internal auditing by demonstrating commitment to implement audit findings.
\end{abstract}

Key words: Internal auditing, Hwange Area, Zimbabwe

\section{Introduction}

This research will focus on internal audit weaknesses observed in Hwange. These weaknesses might also be affecting other companies with internal audit departments in the whole of Zimbabwe. The researcher will try to show the gap between the theoretical role of internal audit as cited in literature and the practical role of internal audit as determined by management of the organization due to their being on the company payroll, and how negative perceptions have impacted on their performance. The internal auditor is aptly described as the mind behind the challenge of the current practice, champion best practice and a facilitator of improvement so that the organisation can achieve its strategic objectives (www.iiasa.org.za).

\subsection{Statement of the problem}

There are a lot of negative perceptions and misconceptions about internal audit. These are caused by several factors such as fear of loss of jobs, lack of knowledge about the functions of audit and fear of the unknown. Some negative perceptions are also caused by people who are after personal gain from company resources. They feel audit will uncover their secrets. So they want to discredit audit as much as possible so that the audit report will not be credible. These negative perceptions have an impact on the performance of the internal audit function. Most companies in Zimbabwe do not have an internal audit function. Those that have the internal audit department, look down upon it. They do not tape from the benefits that accrue from having internal audit.

\subsection{Research objectives}

1) To establish the perceptions of management and staff on internal audit.

2) To determine the causes of negative perceptions about internal audit.

3) To determine how negative perceptions impact on the performance of the internal audit function.

\subsection{Introduction}

\section{Literature Review}

The section focuses on the perceptions that management and staff have on the audit role that is performed by auditors. The literature review will open up possible areas for contextual research in, Zimbabwe, particularly the Hwange Area where the research was carried out. 
Internal audit perceptions and their impact on performance of the internal audit function.

\subsection{Management and workers Perceptions of internal audit}

Millichamp (2002) describes internal audit as an independent appraisal function established by the management of an organization for the review of internal control system as a service to the organization. The above definition shows that the role of internal audit in an organization is the review of internal controls which brings about safeguarding of assets and improved performance. The IIA (2010) explicate internal auditing as an independent, objective assurance and consulting activity designed to add value and improve an organisation's operations. The importance of audit reports is emphasised by Holt and DeZoort (2009) in their research. In an experiment containing company background information, summary accounting results, and numerous governance report options, they find evidence that a descriptive internal audit report significantly affects nonprofessional investor perceptions of company oversight effectiveness and confidence in financial reporting reliability.

Chambers (2012) posits that myths can tell a lot about how others see the world. Sometimes myths may be accurate but they can also mislead. While each of the following myths might be generally untrue, the fact that these myths are so enduring, this might be an indicator that auditors need to find out how they are perceived in their own organization. Chambers (2012) states that some of the myths are that internal auditors are accountants by training, auditors are nit pickers and fault finders, it is best not to tell auditors anything unless they specifically ask and internal audit is the corporate policeman. The researcher agrees with Chambers (2012) that these myths are so alive in the minds of auditees at times but most of them are not true about auditors. The myths even go to the extent of a company deciding to change its auditor because it received a qualified audit opinion.

Aguilar and Barbadillo (2003) state that companies may engage in strategic behaviour to avoid the receipt of a qualified opinion in their audit reports. This behaviour consists of replacing the incumbent auditor by a lower-quality one. This behaviour is limited by the perception that users of the audit reports may have of the auditor change, because companies will seek to reduce the effect that the auditor switch may have by means of reducing the audit quality in ways least likely to be identified by third parties. In these cases, the probability of obtaining a clean report after the auditor change is lower for firms which are subject to a more rigorous monitoring than the rest of the companies.

The researcher differs with the author and feels the above demands by management may compromise internal audit independence. This appears to be a negative perception of internal audit. However, the issue of Audit perceived quality is highly relevant to the client in cases where Audit services are outsourced. Changes of Auditors are initiated by the client due to some dissatisfaction with the former Auditor. In times of economic downturn clients are more sensitive to the relationship between Audit service and Audit fees (Verbruggen et al., 2013).

Sawan and Alzeban (2013) postulate that the internal audit function is inseparably linked with governance given its role within the organization and should therefore be capable of responding to all regulatory requirements. However, the internal audit function is not developed to the same extent in all organizations. In Australia, a large number of listed companies either do not operate an internal audit function at all or employ only one or two staff for this activity (Goodwin and Kent, 2006). In the United States there is evidence (Maher and Akers, 2003) that Chief Executive Officers do not generally want internal audit involvement in the development of organizational systems. Clearly the influence of senior management is a determining force in the scope of the internal audit function as noted by Sarens and DeBeedle (2006). The researcher agrees with the above assertions as there are a few companies with internal audit department in Hwange area, some only have one internal auditor.

Owen (2000) shows that audit need not necessarily be viewed from an essentially negative perspective. He says we should not only be asking what is being achieved in the name of audit but also addressing some very basic matters regarding the type of values that society wishes to prevail. The type of benefits achieved through the work of internal audit. Improvements brought about by implementation of audit recommendations. The researcher agrees with Owen (2000), most of the good work done by the auditor is seldom acknowledged by management. All the credit goes to management for implementing ideas that were introduced by internal audit, and no credit goes to internal audit.

Management perceives internal audit function as expensive to run from within.

Management's view is that adopting a strategic view for outsourcing decisions can lead to a number of benefits including reduced costs, increased flexibility, improved innovation and technical development (Padia et al, 2012). This perception is also supported by Chapman and Anderson (2002) who explains that the new definition of internal auditing as given by the Institute of Internal auditors implies that the internal audit function as an objective activity, does not necessarily have to be established within the organization as the revised definition permits internal audit service to be provided by outsiders who in effect acknowledge that quality internal audit service can now be obtained through outsourcing. This allows for an internal audit to be 
performed by professionals with an in-depth understanding of the business, culture, systems and processes and provide assurance that the internal controls in place are adequate to mitigate the risks.

Abidin and Ismail (2009) suggest that internal audit requires to be sophisticated in the IT field in which it needs to outsource personnel. In light of the large scale business failures such as Enron, WorldCom and Parmalat, one of the most critical functions that failed was auditing. To be effective auditors need to be techno savvy in everything they do during the audit process. In order to effectively audit online systems, auditors need to incorporate online audit software as their primary audit tool.

\subsection{The causes of negative perceptions about Internal audit}

Baskerville et al. (2012) contend that for at least three decades, auditors have been severely criticised as a result of failing to meet society's expectations as a result of the audit expectation-performance gap. Their research findings indicate that the audit expectation- performance gap could be narrowed by adopting a tripartite approach as follows:

(i) ensuring that new issues in the audit arena are widely discussed, and society becomes aware of what

is, and is not, feasible for auditors to accomplish;

(ii) encapsulating in auditing standards the responsibilities society expects of auditors which are costbeneficial for auditors to perform; and

(iii) ensuring auditing standards specify what is required of auditors in fulfilment of their responsibilities and monitoring their performance to ensure the requirements are met. Such measures should align auditors' performance with society's expectations of them, thereby reducing societal criticism and loss of confidence in their work.

Further research by Butcher, Harrison and Ross (2013) shows that if clients are satisfied with or have a favourable perception of certain audit quality attributes of their incumbent auditor, they will remain with the auditor. Auditor retention is influenced by; industry expertise of the audit firm, conduct of audit field work, quality of audit staff and the client's intention to remain loyal to and retain their incumbent auditor.

\subsection{The impact of negative perception on performance of internal audit}

The impact of top management involvement in fraud, corruption and money laundering is that the company will collapse. Such was the case with Enron and WorldCom. The reason is in weak corporate governance. Roussey (2000) says corporate governance is an important part of the capital market and is becoming more important with the growth of global capital markets and with the significant frauds perpetrated in these markets. Negative perceptions in most cases come from those who stand to benefit if an audit is not done, and when an audit is done they are found wanting. It is caused by the desperation to discredit audit for personal gain.

Loss of confidence in the internal audit function is the impact of internal audit expectation gap not met. When auditors fail to do what society or the work force expects them to do, this will cause a negative perception. For example if fraud is being perpetrated openly in a company but auditors fail to pick it, there will be negative perception about audit. The impact is loss of confidence in the internal audit function.

Negative perception of internal audit was created during the financial scandals (Enron and WorldCom) in the United States of America, which resulted in the creation of the Sarbanes Oxley Act of 2002 known as SOX. The scandal involved one of the big Accounting firms in the group known as the Big 4. Clients then lost faith in the Big 4 and started moving to second Tier Audit firms. The impact of this movement resulted in some clients of second Tier Audit firms also moving to Lower Tier Audit firms.

Another cause for negative perception about internal audit is the absence of independence and objectivity in the internal audit function. This assertion is supported by Goodwin and Yeo (2001) when they argue that the independence and objectivity of the internal audit function may be affected by the relationship between internal audit function and the Audit committee. The second reason is the extent to which internal audit function is used as a management training ground and as such is staffed by employees who expect to be transferred to line management positions in the future.

\section{Research Methodology}

The research used an exploratory approach buttressed by a qualitative design. The researchers wanted to gain rich and deep insights into perceptions of management and staff of companies with internal audit committees. The qualitative research results would be used to improve the way internal audit should be viewed in organisations. There are 85 companies in the Hwange area. Out of these companies, only 15 companies have an internal audit department and these are the companies this research focused on. The population is made up of all companies with internal audit departments in the Hwange business community. The research subjects were 330 , being the executive, middle management, supervisors and clerical staff. A questionnaire to gauge 
perceptions on internal audit was used to gather primary data. A sample size of 78 subjects was selected representing $23.64 \%$ of the population.

\section{Research Findings}

The researcher randomly distributed 78 questionnaires to respondents of all grades. Out of these, 69 were answered representing a questionnaire response rate of $88.46 \%$. The major findings of the study were as follows:

Auditors are not fault finders. Internal auditors should not be viewed negatively. The research established that the majority of auditees at all levels of the organisation feared internal auditors. Internal auditing should not be out sourced as that would be expensive to the organisation. In order to effectively audit online systems, internal auditors need to incorporate online audit software as their primary audit tool. Auditor training should be treated as high priority on an organization's budget. It is best to tell auditors even things that auditors do not ask. Management has a significant part to play in order to make internal audit effective.

It was established that negative perceptions come from those who benefit illegally from the company. In most cases of financial statements fraud, corruption and money laundering, top management are involved, thus internal audit becomes an obvious enemy. Negative perceptions about audit are caused by Auditors failure to meet the expectation gap. A bad reputation of an Auditor can result in negative perceptions about that Auditor from both management and workers. A critical dimension of an organization's internal audit function is the quality of its audit staff and their high level of professional competence. Where the audit committee of a company is of low quality, this leads to a low quality internal audit function. Absence of independence and objectivity in the internal audit function causes negative perceptions about the internal audit.

When Auditors fail to do what the society or the workforce expects them to do, this will cause a loss of confidence in the internal audit. Internal audit function is relevant in any business organization, whether profit or non profit. The Audit Committee needs to possess financial expertise and accounting knowledge. Internal auditors get demoralised when their reports are not appreciated by management. If more than $50 \%$ of Audit recommendations are not adopted and implemented by management, then internal audit has no value addition to the organization. Internal audit needs to adopt a new mindset in view of the many changes that are taking place in the Business environment.

\section{Recommendations}

Internal audit needs to adopt a new mindset in view of the many changes that are taking place in the business environment. In the prevalence of financial scandals, intense focus on corporate governance, effective oversight and sound internal controls would assist an organization

The audit structure has to be improved and the internal audit manager should report to the Board (Audit committee). Internal audit should get support from management. Audit should be independent and given correct auditing tools. Top management should accept audit findings and correct errors rather than view audit as fault finders. Audit staff should be qualified and should be adequately remunerated. Management should demonstrated commitment to implement audit findings. Management should respond to all findings and recommendations in time.

Management should cooperate with auditors. Management should give support and allocate adequate resources to internal audit. Management should accept auditors as improvers of the system rather than witch hunters. Auditors should embark on continuous training. Auditors should always be objective and factual. Auditors should be friendly and approachable and constantly strive to improve their performance. Auditors need to have knowledge of the area being audited.

\subsection{Area for future research}

This study was conducted as a case of Hwange Area of Zimbabwe and it only looked at companies with an internal audit department in that area. Therefore, factors causing negative perceptions about internal audit and their impact on the performance of the internal audit function need to be researched in other areas of Zimbabwe. In the case of Hwange, the researcher suggests that a similar study should be conducted but drawing participants from all companies including those that do not have an internal audit department to check whether negative perceptions also exist in these companies and their causes.

\section{References}

[1]. Abidin, Z.A. and Ismail, A.N. (2009) Perceptions towards the importance and knowledge of Information Technology among Auditors in Malaysia. Journal of Accounting and Taxation, Volume 1 pp. $061-069$.

[2]. Gómez-Aguilar, N. and Ruiz-Barbadillo, E. (2003) Do Spanish Firms Change Auditor to Avoid a Qualified Audit Report? International Journal of Auditing. Volume 7 pages 37-53. doi: 10.1111/1099-1123.00004.

[3]. Baskerville et al. (2012) Audit expectation - performance gap revisited: Evidence from New Zealand and United Kingdom part 2: Changes in the gap in New Zealand 1989 - 2008 and in the United Kingdom 1999 - 2008. International Journal of Auditing. Volume 16 pages $215-247$. 
[4]. Butcher K., Harrison, G. and Ross, P. (2013) Perceptions of Audit service quality and Auditor retention: International Journal of Auditing, Volume 17 pages $54-74$

[5]. Chapman, C. and Anderson, U. (2002) Implementing the professional Practice Framework. Altermoute: The Institute of Internal auditors.

[6]. Goodwin-Stewart, J. and Kent, P. (2006) The use of internal audit by Australian companies. Managerial Auditing Journal. Volume 21 Issue: 1 , Pages $81-101$.

[7]. Goodwin, J. and Yeo, T.Y. (2001) Two factors affecting Internal audit independence and objectivity: Evidence from Singapore. International Journal of Auditing. Volume 5 pages $107-125$.

[8]. Holt, T.P. and DeZoort, T. (2009) The Effects of Internal audit Report: Disclosure on Investor Confidence and Investment Decisions. International Journal of Auditing. Volume 13 pages 61-77.

[9]. IIA (2010) IPPF Practice guide - Auditing Executive compensation and benefits. www.theiia.org/guidance accessed on 16 November 2014

[10]. Millichamp, A.H. (2002) Auditing, Illustrated edition. Cengage Learning EMEA

[11]. Padia et al. (2012) Internal audit Function, current status and perception of outsourcing. African Journal of Business Management. Volume 6. Pages $11828-11838$.

[12]. Roussey, R.S. (2000) A case for Global corporate governance rules: An Auditor perspective. International Journal of Auditing. Volume 4 (pp $203-211)$.

[13]. Sarens, G. and De Beelde, I. (2006) The Relationship between Internal audit and Senior Management: A Qualitative Analysis of Expectations and Perceptions. International Journal of Auditing. Volume 10. Pages 219-241.

[14]. Verbruggen, S., Caneghem, T.V. and Reheul, A.M. (2013) Auditor performance, Client satisfaction and client loyalty: Evidence from Belgium Non - Profits. International Journal of Auditing. Volume 17 pp $19-37$.

[15]. $\quad$ www.iiasa.org.za accessed on 15 November 2013 